\title{
On the role of mesoscale eddies for the biological productivity and biogeochemistry in the eastern tropical Pacific Ocean off Peru
}

\author{
L. Stramma ${ }^{1}$, H. W. Bange ${ }^{1}$, R. Czeschel ${ }^{1}$, A. Lorenzo ${ }^{2}$, and M. Frank ${ }^{3}$ \\ ${ }^{1}$ Helmholtz Centre for Ocean Research Kiel (GEOMAR), Düsternbrooker Weg 20, 24105 Kiel, Germany \\ ${ }^{2}$ Instituto del Mar del Peru (IMARPE), Coastal Laboratory of Pisco, Paracas-Pisco, Peru \\ ${ }^{3}$ Helmholtz Centre for Ocean Research Kiel (GEOMAR), Wischhofstraße 1-3, 24148 Kiel, Germany
}

Correspondence to: L. Stramma (lstramma@geomar.de)

Received: 22 May 2013 - Published in Biogeosciences Discuss.: 10 June 2013

Revised: 11 October 2013 - Accepted: 13 October 2013 - Published: 14 November 2013

\begin{abstract}
Mesoscale eddies seem to play an important role for both the hydrography and biogeochemistry of the eastern tropical Pacific Ocean (ETSP) off Peru. However, detailed surveys of these eddies are not available, which has so far hampered an in depth understanding of their implications for nutrient distribution and biological productivity. In this study, three eddies along a section at $16^{\circ} 45^{\prime} \mathrm{S}$ have been surveyed intensively during R/V Meteor cruise M90 in November 2012. A coastal mode water eddy, an open ocean mode water eddy and an open ocean cyclonic eddy have been identified and sampled in order to determine both their hydrographic properties and their influence on the biogeochemical setting of the ETSP. In the thermocline the temperature of the coastal anticyclonic eddy was up to $2{ }^{\circ} \mathrm{C}$ warmer, 0.2 more saline and the swirl velocity was up to $35 \mathrm{~cm} \mathrm{~s}^{-1}$. The observed temperature and salinity anomalies, as well as swirl velocities of both types of eddies were about twice as large as had been described for the mean eddies in the ETSP. The observed heat and salt anomalies (AHA, ASA) of the anticyclonic eddy near the shelf-break of $17.7 \times 10^{18} \mathrm{~J}$ and $36.6 \times 10^{10} \mathrm{~kg}$ are more than twice as large as the mean AHA and ASA for the ETSP. We found that the eddies contributed to the productivity by maintaining pronounced subsurface maxima of chlorophyll of up to $6 \mu \mathrm{g} \mathrm{L}^{-1}$. Based on a comparison of the coastal (young) mode water eddy and the open ocean (old) mode water eddy we suggest that the ageing of eddies when they detach from the shelf-break and move westward to the open ocean influences the eddies' properties: chlorophyll maxima are reduced to about half $\left(2.5-3 \mu \mathrm{g} \mathrm{L}^{-1}\right)$ and nutrients are subducted. However, different settings at the time of formation may also contribute to the observed dif-
\end{abstract}

ferences between the young and old mode water eddies. The coastal mode water eddy was found to be a site of nitrogen (N) loss in the $\mathrm{OMZ}$ with a maximum $\Delta \mathrm{NO}_{3}^{-}$anomaly (i.e. $\mathrm{N}$ loss) of about $-25 \mu \mathrm{mol} \mathrm{L}^{-1}$ in $250 \mathrm{~m}$ water depth, whereas, the open ocean mode water and cyclonic eddies were of minor and negligible importance for the $\mathrm{N}$ loss, respectively. Our results show that the important role of eddies for the distribution of nutrients, as well as biogeochemical processes in the ETSP (and other OMZ/upwelling regions) can only be fully deciphered and understood through dedicated high spatial and temporal resolution oceanographic/biogeochemical surveys.

\section{Introduction}

During the last two decades nonlinear mesoscale features of the oceanic circulation (so called eddies) have been recognised to play an important role for the vertical and horizontal transport of momentum, heat, mass and the chemical constituents of seawater, such as oxygen, nutrients, etc. (e.g. Klein and Lapeyre, 2009). Three types of eddies have been identified: cyclonic, anticyclonic and mode water eddies (e.g. McGillicuddy Jr. et al., 2007). Mode water eddies derive their name from the thick lens of water that deepens the main pycnocline while shoaling the seasonal pycnocline. Because the geostrophic velocities are dominated by the depression of the main thermocline, the direction of rotation of mode water eddies is the same as of anticyclonic eddies (McGillicuddy Jr. et al., 2007). Nutrients are supplied for new production where isopycnals from the subsurface outcrop at the base of the 
euphotic zone, primarily at fronts (Mahadevan and Archer, 2000). Thus, cyclonic eddies (cyclones) and mode water eddies can inject nutrients from below the euphotic zone into the euphotic zone while anticyclonic eddies (anticyclones) tend to decrease the nutrient content of the euphotic zone (e.g. Klein and Lapeyre, 2009). The enhanced upwelling of nutrients into the euphotic zone by eddies (i.e. eddy pumping) is especially important for the biological productivity of the oligotrophic regions of the oceans (McGillicuddy Jr. et al., 1998, 2007; Oschlies and Garcon, 1998; Levy et al., 2001). Only recently, however, Gruber et al. (2011) suggested that the occurrence of eddies in coastal upwelling regions, which are characterised by a high productivity, may result in a reduction of biological production.

In the eastern tropical Pacific Ocean the zonal tropical current bands supply oxygen $\left(\mathrm{O}_{2}\right)$ rich water to the oxygen minimum zone (OMZ) (Stramma et al., 2010b). In contrast, the mid-depth circulation in the eastern South Pacific Ocean is sluggish in the region of the OMZ. As the mean currents are weak, eddy variability strongly influences the flow and ultimately supplies oxygen-poor water to the OMZ (Czeschel et al., 2011). Model results support the view that eddies are responsible for the redistribution of oxygen within the OMZ and for the oxygen transport at the poleward boundary of the OMZ (N. Gruber, personal communication, 2012). In the eastern Pacific hydrographic parameter vary seasonally and especially related to the El Nino phase (e.g. Czeschel et al., 2012) hence a comparison of a single survey to the mean field probably does not lead to stable results.

On the basis of $15 \mathrm{yr}$ of satellite altimetry measurements an analysis of the mean eddy properties offshore the Peruvian coast showed that eddies are highly abundant off Peru, most frequently observed off Chimbote $\left(9^{\circ} \mathrm{S}\right)$ and south of San Juan $\left(15^{\circ} \mathrm{S}\right)$ (Chaigneau et al., 2008). The highest eddy frequency was found between $15^{\circ} \mathrm{S}$ and $18^{\circ} \mathrm{S}$ east of $90^{\circ} \mathrm{W}$. In recent studies, measurements of three anticyclonic eddies in the eastern tropical South Pacific Ocean were performed. Two of them featured depressed near-surface isopycnals whereas one exhibited doming isopycnals (Holte et al., 2013). An anticyclonic eddy described off central-southern Chile (Morales et al., 2012) showed the typical mode water eddy distribution.

Mesoscale variability occurs in the form of linear Rossby waves and as nonlinear vortices or eddies. In contrast to linear waves, nonlinear vortices can transport momentum, heat, mass and the chemical constituents of seawater, and therefore contribute to the large scale water mass distribution (e.g. Chelton et al., 2007). The degree of nonlinearity of a mesoscale feature is characterised by the ratio of the rotational fluid speed $U$ to the translation speed $c$ of the feature. When $U / c>1$, the feature is nonlinear, which allows it to maintain a coherent structure as it propagates (e.g. Flierl, 1981; Chelton et al., 2011).

Marine primary production is governed by temperature, light, and limiting nutrients, most notably nitrogen $(\mathrm{N})$, phos- phorus $(\mathrm{P})$, silicon $(\mathrm{Si})$ and iron $(\mathrm{Fe})$ depending on plankton species. A fraction of the biologically produced particulate matter subsequently sinks into the subsurface ocean where it is consumed by microbes and macrofauna, releasing carbon dioxide $\left(\mathrm{CO}_{2}\right)$ and nutrients back to the water column and consuming subsurface $\mathrm{O}_{2}$ (Doney, 2010). In case of slow rates of water renewal in subsurface layers this leads to low oxygen concentrations and as increasing $\mathrm{CO}_{2}$ leads to lower pH values (e.g. Feely et al., 2008) the low oxygen waters also become increasingly "acidified" and more corrosive to carbonates.

The coastal upwelling region of Peru belongs to the four major eastern boundary upwelling systems and thus shows an overall very high biological production (e.g. Chavez and Messié, 2009). The upwelling is fed by nutrient-rich/oxygendepleted waters of the poleward flowing Peru-Chile Undercurrent (Brink et al., 1983; Huyer et al., 1991). The productivity off Peru is not only fueled by nutrients such as "new" nitrate originating from upwelled water masses, but a significant fraction of the productivity also results from regenerated nitrate in the euphotic zone (Fernández et al., 2009). The Peruvian upwelling is adjacent to the OMZ in the eastern tropical South Pacific Ocean (ETSP), which is one of three major oxygen minimum zones of the global ocean (Karstensen et al., 2008; Paulmier and Ruiz-Pino, 2009). The oxygen concentrations in the OMZ of the ETSP are generally very low $\left(<20 \mu \mathrm{mol} \mathrm{L}^{-1}\right)$. Therefore, it is also an oceanic region where a significant microbial loss of fixed nitrogen (Codispoti, 2007; Gruber, 2008) (i.e. bioavailable nitrogen mainly in the form of inorganic nitrogen containing nutrients) takes place (Thamdrup et al., 2012; Lam et al., 2009). The processes involved are denitrification (reduction of nitrate via nitrite to dinitrogen), anammox (anaerobic oxidation of ammonium with nitrite to dinitrogen) and DNRA (dissimilatory nitrate reduction to ammonium).

By combining historical records of Argo float profiles and satellite data the three-dimensional eddy structure of the eastern South Pacific Ocean was described for temperature, salinity, density and velocity fields of cyclonic and anticyclonic eddies (Chaigneau et al., 2011). The core of cyclonic eddies is centred at $\sim 150 \mathrm{~m}$ while the core of anticyclonic eddies is located at $\sim 400 \mathrm{~m}$ depth. These differences are attributed to their formation mechanisms as cyclonic eddies are formed by instabilities of the equatorward coastal surface currents, whereas the anticyclonic eddies are likely released from the poleward subsurface Peru-Chile Undercurrent (Chaigneau et al., 2011). The mean radius of the eastern South Pacific Ocean eddies was estimated to be $122 \pm 30 \mathrm{~km}$ (Chaigneau et al., 2011). The high eddy activity in austral spring (October to November) near $15^{\circ} \mathrm{S}$ coincides with areas of reduced upwelling and an important inshore advection of warmer and saltier subtropical water from $9^{\circ} \mathrm{S}$ to $16^{\circ} \mathrm{S}$ (Chaigneau et al., 2008).

Correa-Ramirez et al. (2012) suggested that the observed seasonal discrepancy between the occurrence of the 
maximum upwelling (in austral winter) and satellite observation of the maximum chlorophyll concentrations (in austral summer) in the coastal area of Peru may be caused by an intensification and seasonal displacement of eddy kinetic energy associated with eddies north of $20^{\circ} \mathrm{S}$. Moreover, coastal eddies off Peru have been shown to be sites of significant loss of fixed nitrogen (Altabet et al., 2012). Therefore, eddies off Peru seem to play an important role for biological productivity and the nitrogen cycle. However, our knowledge is mainly based on model studies and satellite observations but actual (i.e. in-situ) hydrographic and biogeochemical features of the eddies off Peru are largely unknown. Here we present the results of a first detailed survey of hydrographic and biogeochemical parameters of three eddies off Peru in order to elucidate their role for the biogeochemical cycling in the ETSP.

\section{Observational data}

Cruise M90 on the German research vessel R/V Meteor took place in November 2012 to investigate the factors controlling the intensity and areal extent of the OMZ of the eastern tropical Pacific Ocean. The cruise started in Cristobal, Panama, on 29 October and ended on 28 November in Callao, Peru. Starting on 15 November a former World Ocean Circulation Experiment (WOCE) section along $16^{\circ} 45^{\prime} \mathrm{S}$ sampled in April 1994 was reoccupied by following an eastward cruise track from $87^{\circ} \mathrm{W}$ to the coast of Peru. On the basis of satellite sea level height anomaly images forwarded to the ship and which revealed two major anticyclonic eddies and one cyclonic eddy along the section (Fig. 1), a detailed survey of these eddies including acoustic Doppler current profiling (ADCP), measurements of conductivity/temperature/depth (CTD), and of major biogeochemical parameters $\left(\mathrm{O}_{2}\right.$, nutrients, chlorophyll, turbidity and $\mathrm{pH}$ ) along several additional subsections across the eddies have been performed (Fig. 1). The surveys were carried out on 16 to 18 November for section B, on 20 and 21 November for section C, on 22 and 23 November for section A2 and on 24 and 25 November for section A1.

Two ADCP systems recorded the ocean velocities: a hull mounted RDI OceanSurveyor $75 \mathrm{kHz}$ ADCP provided the velocity distribution to about $700 \mathrm{~m}$ depth, while a $38 \mathrm{kHz}$ ADCP mounted in the sea-well provided velocity profiles down to about $1200 \mathrm{~m}$ depth. Given that the eddies are centred in the upper ocean the data shown in this study for the upper ocean are exclusively from the $75 \mathrm{kHz}$ ADCP, which has a higher resolution in the upper ocean. The $38 \mathrm{kHz}$ ADCP data are used to determine the swirl velocities below $700 \mathrm{~m}$ depth.

A Seabird CTD system with a GO rosette with $2410 \mathrm{~L}$-water bottles was used for water profiling and discrete water sampling. The CTD system was used with double sensors for temperature, conductivity (salinity) and oxygen. The CTD oxygen sensor was calibrated with oxygen mea-
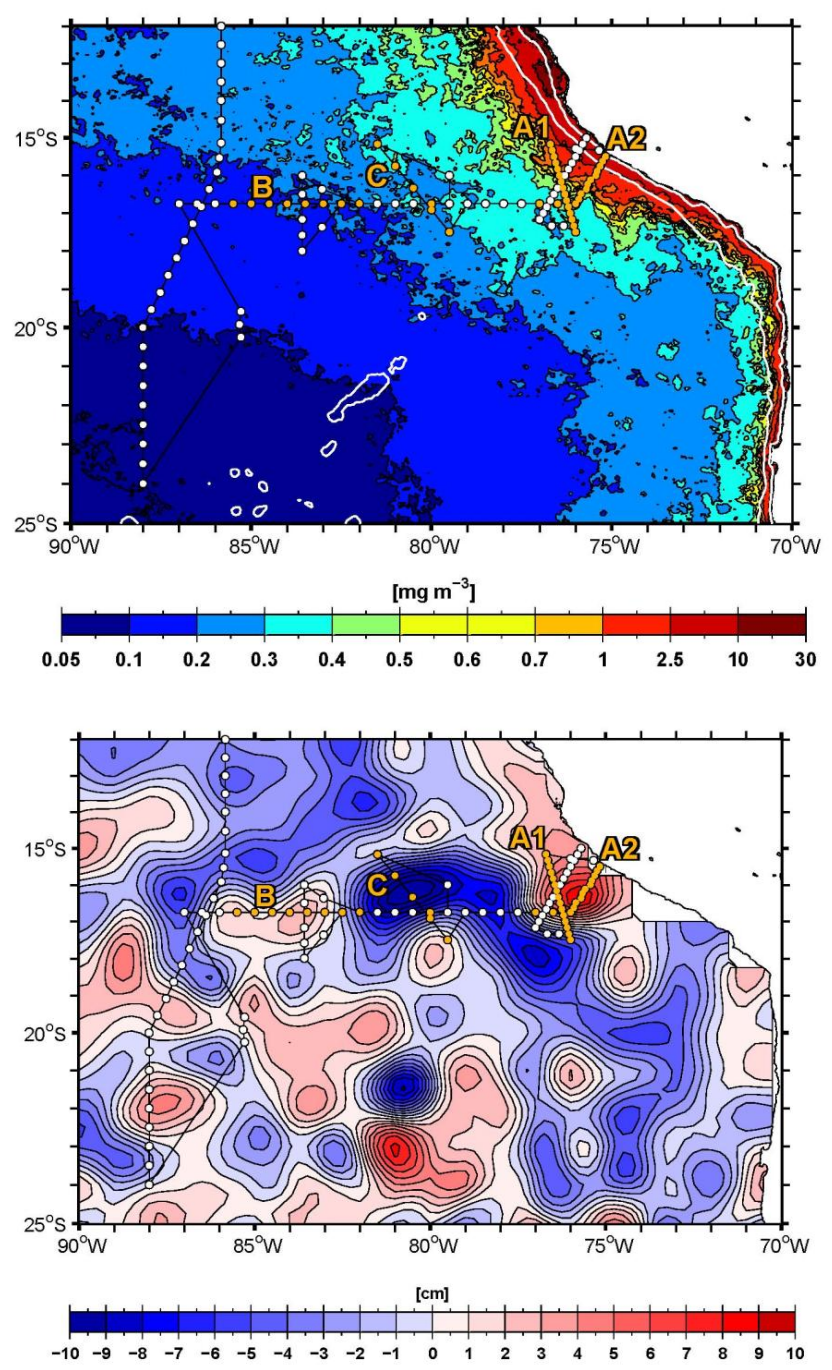

Fig. 1. Mean monthly November 2002 to 2011 chlorophyll data binned spatially and temporally over the entire month with the $200 \mathrm{~m}$ and $2000 \mathrm{~m}$ depth contours included as white lines (top) and Aviso sea level height anomaly (in cm) for 21 November 2012 (bottom), cyclonic features are shown in blue, anticyclonic ones in red. The cruise track (black line) and CTD stations (white and yellow dots) of R/V Meteor cruise M90 are included. Stations used for section plots are marked by yellow dots and are named A1, A2, $\mathrm{B}$ and $\mathrm{C}$.

surements obtained from discrete samples from the rosette applying the classical Winkler titration method using a nonelectronic titration stand (Winkler, 1888; Hansen, 1999). The precision of the oxygen titration was $\pm 0.45 \mu \mathrm{mol} \mathrm{L}-1$. The uncertainty of the CTD oxygen sensor calibration was determined as a r.m.s. of $\pm 0.68 \mu \mathrm{mol} \mathrm{O}_{2} \mathrm{~kg}^{-1}$. However, with the classical titration method, we were not able to determine oxygen concentrations below about $2 \mu \mathrm{mol} \mathrm{kg}{ }^{-1}$ and hence oxygen concentrations below about $2 \mu \mathrm{mol} \mathrm{kg}{ }^{-1}$ could not be measured with the CTD oxygen sensor. Turbidity given in NTU (Nephelometric Turbidity Units) and 
chlorophyll concentrations $\left(\mu \mathrm{g} \mathrm{L}^{-1}\right)$ were measured with a WetLabs FLNTU instrument attached to the CTD. We used the original calibration provided by the company with sensitivities of $0.01 \mathrm{NTU}$ and $0.025 \mu \mathrm{g} \mathrm{\textrm {L } ^ { - 1 }}$ but did not apply any shipboard calibration and hence the measured absolute values may have a somewhat larger uncertainty, but the gradients determined across the eddies are clearly reliable. As the chlorophyll data are only company calibrated we will mark the units as (cc) $\mu \mathrm{g} \mathrm{L} \mathrm{L}^{-1}$.

Nutrients were measured on-board with a QuAAtro auto-analyser (Seal Analytical). Nitrite $\left(\mathrm{NO}_{2}^{-}\right)$, nitrate $\left(\mathrm{NO}_{3}^{-}\right)$, phosphate $\left(\mathrm{PO}_{4}^{3-}\right)$ and silicate $\left(\mathrm{SiO}_{2}\right)$ were measured with a precision of $\pm 0.1 \mu \mathrm{mol} \mathrm{L}{ }^{-1}, \pm 0.1 \mu \mathrm{mol} \mathrm{L}{ }^{-1}$, $\pm 0.02 \mu \mathrm{mol} \mathrm{L}^{-1}$ and $\pm 0.24 \mu \mathrm{mol} \mathrm{L}{ }^{-1}$, respectively. $\mathrm{N}^{*}$ was calculated as $\mathrm{N}^{*}=\left(\mathrm{NO}_{3}^{-}+\mathrm{NO}_{2}^{-}\right)-16 \mathrm{PO}_{4}^{3-}$ (see Altabet et al. (2012) and references therein).

The $\mathrm{pH}$ measurements were carried out with a Mettler Toledo potentiometer, model SevenGo, with an InLab 413 SG IP67 electrode calibrated with buffer solutions at $\mathrm{pH}$ values 4, 7 and 10 .

Eddy core anomalies were calculated as the difference between concentrations measured at the stations at the edge of the eddy and those in its centre. As we can only use stations available from our measurements, the definition of the eddy core and the eddy boundary might differ to the real eddy core and boundary. The locations chosen for comparison are marked in the figures representing each section. The available heat anomalies (AHA) and available salt anomalies (ASA) were computed as described in Chaigneau et al. (2011). For AHA and ASA the maximum of swirl velocity from the ADCP was defined on both sides of the eddy for each depth and then temperature and salinity were interpolated on an equidistant grid between these boundaries from all existing profiles along the section and the gridded field was used for the AHA and ASA computation.

Aviso satellite derived altimeter sea surface height anomaly data (SSHA) were used to define the general distribution of eddies and to identify their individual spatial extent during the cruise and their generation and path in time. The SSHA data used in this study are delayed time products and combine available data of all satellites. The data are resampled on a regular $0.25^{\circ} \times 0.25^{\circ}$ grid and are calculated with respect to a seven-year mean (http://www.aviso. oceanobs.com). For the overview figure (Fig. 1b) the delayed time 7 day mean SSHA image was used, while for tracking the eddy movement the daily final near real time products were used. The eddies were tracked for each day and for selected days the centre was taken at the location of the largest SSHA deviation. MODIS-aqua satellite derived chlorophyll data were used for a better visualisation of the distribution of chlorophyll at the surface of the coastal eddy. The chlorophyll data provided by the Giovanni data portal (http:// disc.sci.gsfc.nasa.gov/giovanni/additional/users-manual) are either a monthly mean image for all November data 2002 to
2011 (Fig. 1a) or averaged for each grid cell over a time range of 8 days with a resolution of $1 / 24^{\circ} \times 1 / 24^{\circ}$.

The focus of the investigation is on the measured parameters hence the eddy boundaries are defined from the measured profiles together with the high resolution ADCP data. Using the satellite data to define the boundaries might result in locations not measured. The satellite data derived with interpolation schemes from available satellite paths do not represent the subsurface parameter distribution in the eddy.

\section{Results}

\subsection{Eddies off southern Peru}

Several anticyclonic (counter-clockwise rotation in the Southern Hemisphere) and cyclonic features were clearly visible in the SSHA data in the region off Peru at the time of cruise M90 in November 2012 (Fig. 1b). Along the $16^{\circ} 45^{\prime} \mathrm{S}$ section one anticyclonic eddy (eddy B) was centred in the open ocean at about $17^{\circ} \mathrm{S}, 83^{\circ} 30^{\prime} \mathrm{W}$ and another anticyclonic eddy (eddy A) was centred close to the shelf-break at about $16^{\circ} \mathrm{S}, 76^{\circ} \mathrm{W}$. These two features offered the possibility to compare a young eddy (i.e. eddy A) formed near the shelf-break with an older open ocean eddy (i.e. eddy B). Along the $16^{\circ} 45^{\prime} \mathrm{S}$ section a large cyclonic eddy (i.e. eddy C) was centred with maximum SSHA at $16^{\circ} 15^{\prime} \mathrm{S}, 80^{\circ} 15^{\prime} \mathrm{W}$ on 21 November 2012 with a strong southwest to northeast extension.

\subsection{The anticyclonic eddy off Peru (eddy A)}

Anticyclonic eddy A was located off the Peruvian shelfbreak in late November 2012. An overview of the measured velocity and parameter distributions shows the opposing directions of the flow and the corresponding velocities of the anticyclonic circulation and the oxygen minimum core in the centre of the eddy where the zonal $(u)$ and meridional $(v)$ velocity components change direction (Fig. 2). The largest anomalies were observed in the upper $600 \mathrm{~m}$, but the anticyclonic velocity components were still seen at the greatest depths reached with the shipboard ADCP at about $1200 \mathrm{~m}$. As described for other anticyclonic eddies (Chaigneau et al., 2011), the highest meridional speed occurred between $50 \mathrm{~m}$ and $250 \mathrm{~m}$ depth. The density distribution shows a deepening of the isopycnals below $110 \mathrm{~m}$ and an uplift above $110 \mathrm{~m}$ which is typical for a mode water eddy. Connected to the uplift of the isopycnals, the anticyclonic swirl velocity derived as the mean of maximum positive and negative velocity perpendicular to the section used at each depth decreased above $110 \mathrm{~m}$ (Fig. 3). The corresponding salinity and temperature was elevated in the centre of the eddy (Chaigneau et al., 2011).

Given that oxygen is generally low below 30-50 m water depth in the eastern tropical Pacific Ocean, only a weak further reduction in oxygen is possible. Nevertheless the oxygen 

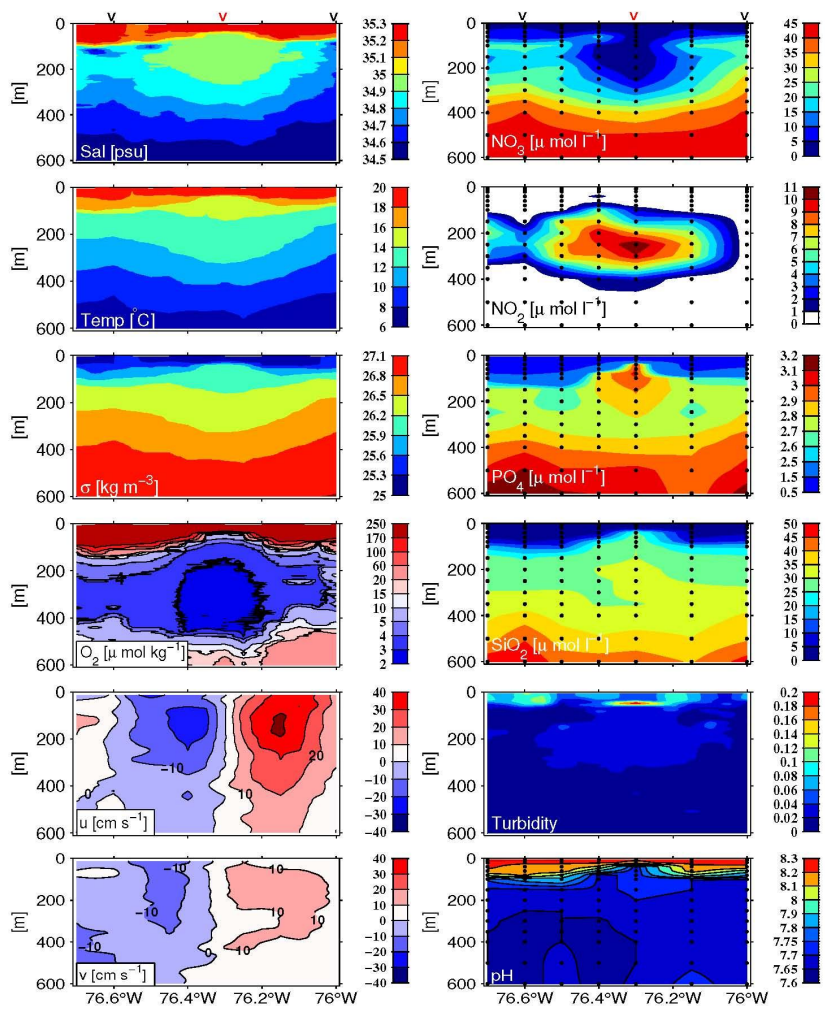

Fig. 2. Parameter distribution in the anticyclonic eddy A off the Peruvian shelf along section $\mathrm{A} 1$ from $15^{\circ} 10^{\prime} \mathrm{S}, 76^{\circ} 42^{\prime} \mathrm{W}$ to $17^{\circ} 30^{\prime} \mathrm{S}$, $76^{\circ} \mathrm{W}$ (see Fig. 1) on 24 and 25 November 2012 for salinity, temperature, density, oxygen concentrations and zonal (u, positive eastward) and meridional (v, positive northward) ADCP velocity components (left), nitrate, nitrite, phosphate, silicate concentrations, turbidity and $\mathrm{pH}$ (right). For bottle data of the nutrient concentrations and $\mathrm{pH}$ the sampling depths are marked by black dots. To compute the eddy core anomalies in Fig. 3, the two outside profiles used are marked on top with a black $\mathrm{v}$ and the core profile with a red $\mathrm{v}$.

minimum linked to the eddy is clearly visible in the section across the eddy (Fig. 2). There is a pronounced decrease of the oxygen concentrations by more than $200 \mu \mathrm{mol} \mathrm{kg}-1$ from the surface to $50 \mathrm{~m}$ depth (Fig. 3) where the uplift of the near surface isopycnals led to a significant shoaling of the mixed layer. Nitrate was reduced at $100-300 \mathrm{~m}$ depth by $\sim 20 \mu \mathrm{mol} \mathrm{L}^{-1}$ and nitrite increased at $100-500 \mathrm{~m}$ depth. A pronounced increase in phosphate and silicate concentration was observed between $50 \mathrm{~m}$ and $150 \mathrm{~m}$ depth. Turbidity was higher at about $50-400 \mathrm{~m}$ depth and the $\mathrm{pH}$ was generally higher between $100 \mathrm{~m}$ and $400 \mathrm{~m}$ depth, but displayed the highest decreasing gradient from the surface down to around $50 \mathrm{~m}$ depth (Fig. 3). The chlorophyll distribution in the upper ocean was characterised by a very large chlorophyll maximum of 6.1 (cc) $\mu \mathrm{g} \mathrm{L}^{-1}$ in the core of uprising isopycnals at $45 \mathrm{~m}$ to $55 \mathrm{~m}$ depth for the centre of the anticyclone (Fig. 4) connected to a positive turbidity anomaly of $0.1 \mathrm{NTU}$ (Fig. 3). The increased chlorophyll values near the surface at
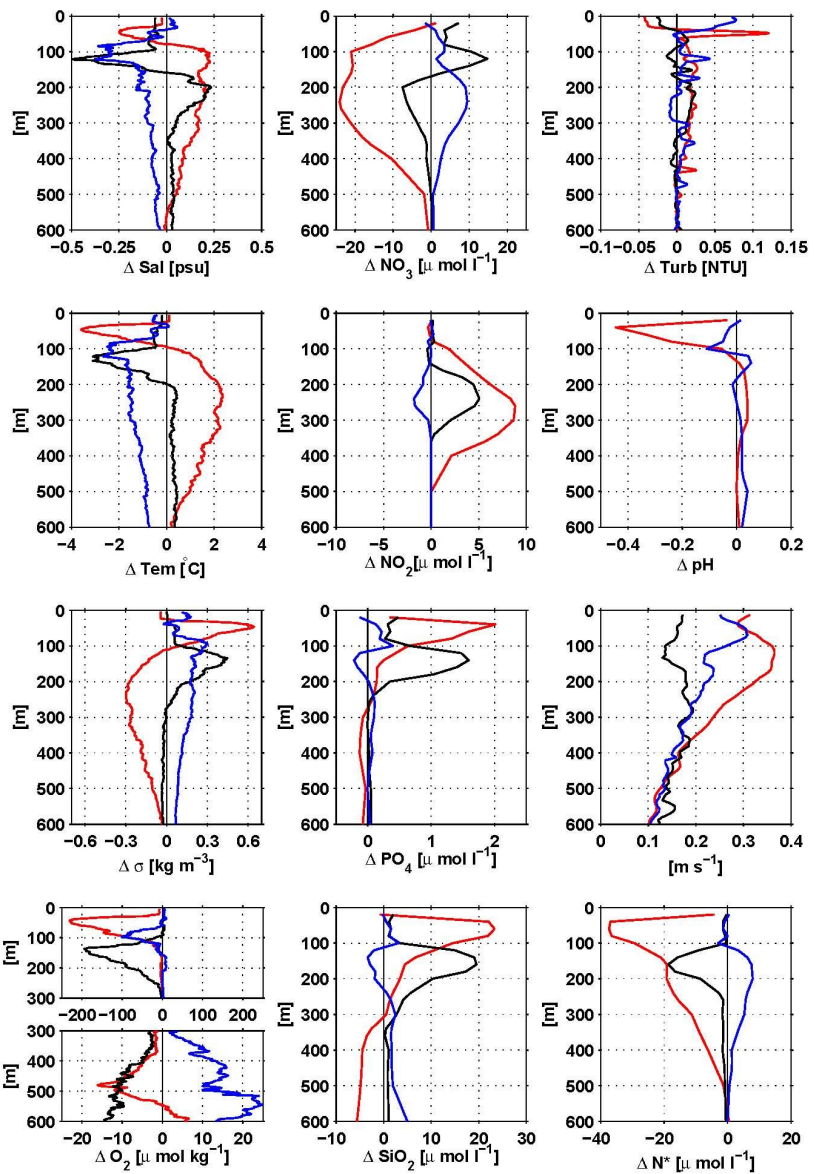

Fig. 3. Eddy core anomalies from the difference between the mean of the two profiles outside the eddy and in the profile in the eddy core (as marked by red and black v's in the section plots) versus depth for salinity, temperature, density and oxygen concentration (left), nitrate, nitrite, phosphate, and silicate concentration (middle), turbidity, $\mathrm{pH}$, swirl velocity and $\mathrm{N}^{*}$ (right) for the near-shelf anticyclonic eddy A (see Fig. 2) between $76.6^{\circ} \mathrm{W}$ and $76^{\circ} \mathrm{W}$ (red lines), the open ocean anticyclonic eddy B (see Fig. 7) between $85^{\circ} 30^{\prime} \mathrm{W}$ and $82^{\circ} 30^{\prime} \mathrm{W}$ (black lines) and the cyclonic eddy $\mathrm{C}$ (see Fig. 8) between $15^{\circ} \mathrm{S}$ and $17.5^{\circ} \mathrm{S}$ (blue lines). For oxygen the $x$ axis is changed at $300 \mathrm{~m}$ depth to better resolve the small changes at depth.

$76.6^{\circ} \mathrm{W}$ to $76.7^{\circ} \mathrm{W}$ were related to high near coastal chlorophyll values, which were visible in chlorophyll satellite images taken at the end of November 2012 (Fig. 5) and which were transported offshore at the northern rim of the anticyclone. While the mean November surface chlorophyll distribution shows a large high chlorophyll layer reaching off the shelf-break (Fig. 1a), the surface chlorophyll is strongly reduced in mid-November 2012 in the area of the eddy A flow component towards the shelf (Fig. 5).

According to sea level anomaly images this anticyclone was formed after 13 September 2012. It appeared first on 14 September 2012 at $16^{\circ} 15^{\prime} \mathrm{S} 75^{\circ} \mathrm{W}$. It moved to $16^{\circ} 15^{\prime} \mathrm{S}$, $76^{\circ} \mathrm{W}$ on 1 November 2012 with a mean westward velocity 

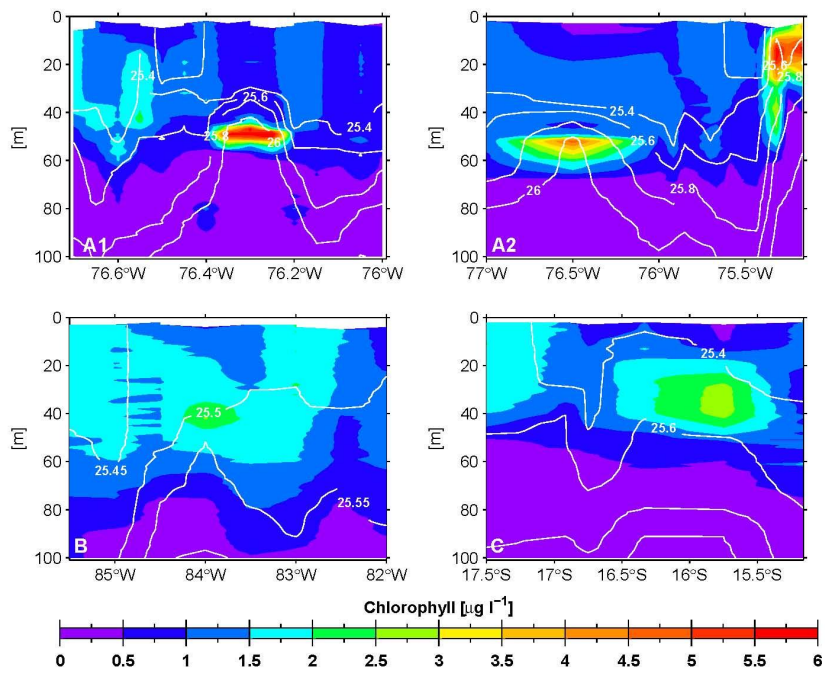

Fig. 4. Chlorophyll distribution in the upper $100 \mathrm{~m}$ from a company calibrated only WetLabs FLNTU, units are given in (cc) $\mu \mathrm{L} \mathrm{L}^{-1}$ (see text) for the anticyclones A, section $\mathrm{A} 1$ from $15^{\circ} 10^{\prime} \mathrm{S}, 76^{\circ} 42^{\prime} \mathrm{W}$ to $17^{\circ} 30^{\prime} \mathrm{S}, 76^{\circ} \mathrm{W}$ (top left; see Fig. 2), section A2 along $16^{\circ} 45^{\prime} \mathrm{S}$ to the shelf (top right; see Fig. 6), B along $16^{\circ} 45^{\prime} \mathrm{S}$ between $85^{\circ} 30^{\prime} \mathrm{W}$ and $82^{\circ} \mathrm{W}$ (bottom left; see Fig. 7) and the cyclone $\mathrm{C}$ between $17^{\circ} 30^{\prime} \mathrm{S}, 79^{\circ} 30^{\prime} \mathrm{W}$ and $15^{\circ} 10^{\prime} \mathrm{S}, 81^{\circ} 30^{\prime} \mathrm{W}$ (bottom right; see Fig. 8). Density contours are included as white lines with $0.2 \mathrm{~kg} \mathrm{~m}^{-3}$ spacing except for section B with $0.05 \mathrm{~kg} \mathrm{~m}^{-3}$ spacing to resolve the weak density gradient.

of $2.6 \mathrm{~cm} \mathrm{~s}^{-1}$. In November the eddy strengthened and stayed stationary near the shelf-break until mid-December 2012. The anticyclone was centred at $16^{\circ} 15^{\prime} \mathrm{S}, 76^{\circ} \mathrm{W}$ on 21 November 2012, hence it was 2 months old at the time the profiles were taken. On 15 December the eddy was still in the same region at $16^{\circ} 15^{\prime} \mathrm{S}, 75^{\circ} 45^{\prime} \mathrm{W}$ then started to move westward and could be tracked to $15^{\circ} 15^{\prime} \mathrm{S}, 81^{\circ} \mathrm{W}$ at 25 March 2013. The westward movement of 5 degrees in 100 days translates into a westward transit speed of $6.1 \mathrm{~cm} \mathrm{~s}^{-1}\left(6.6 \mathrm{~cm} \mathrm{~s}^{-1}\right.$ northwestward).

The section A2 along $16^{\circ} 45^{\prime} \mathrm{S}$ that changed to northeasterly direction towards the shelf at $76^{\circ} \mathrm{W}$ (Fig. 6) crossed the southern part of anticyclonic eddy A (Fig. 1b). Different to the impression from SSHA (Fig. 1b) the eddy core was located west of $76^{\circ} \mathrm{W}$. The SSHA figures show different eddy core locations for near real time data and delayed time processing. The near real time data for 21 November 2012 showed the eddy core west of $76^{\circ} \mathrm{W}$ and the SSHA fields cannot be used for determining the exact eddy core. The section A2 document the isolated low oxygen core of the eddy west of $76^{\circ} \mathrm{W}$ and the low oxygen core right at the shelf-break. Salinity, temperature and density again showed the signature of the mode water type eddy and upwelling in the upper $150 \mathrm{~m}$ near the shelf-break (Fig. 6, left). The chlorophyll distribution (Fig. 4) shows the eddy related core of 4.7 (cc) $\mu \mathrm{g} \mathrm{L}^{-1}$ at $76^{\circ} 30^{\prime} \mathrm{W}$ in uprising isopycnals at 50

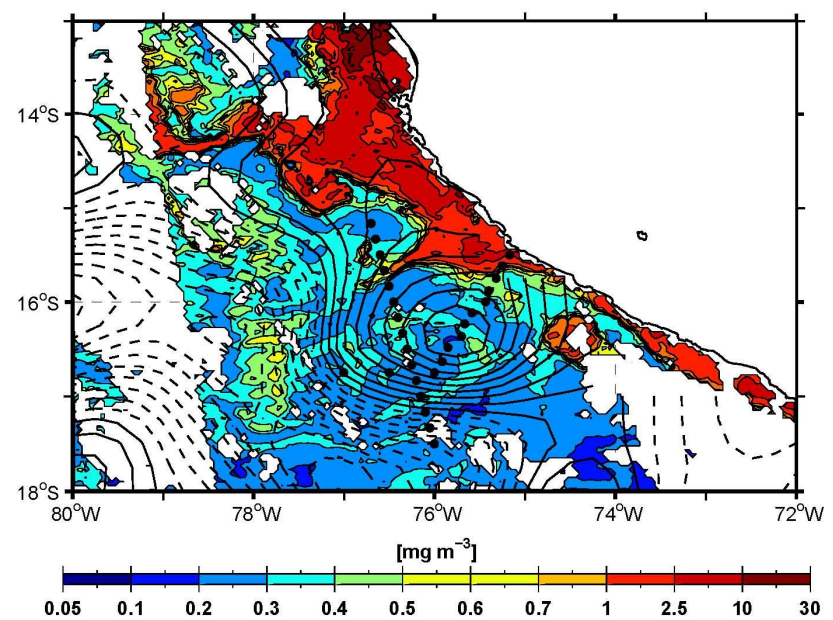

Fig. 5. Mean sea surface chlorophyll distribution (in $\mathrm{mg} \mathrm{m}^{-3}$ ) for 16 to 24 November 2012 from MODIS-aqua (colour) with SSHA (in cm; contour interval $1 \mathrm{~cm}$ ) for 21 November 2012 (black lines) as shown in Fig. 1.

to $60 \mathrm{~m}$ depth and with $5.7(\mathrm{cc}) \mu \mathrm{g} \mathrm{L^{-1 }}$ in the upper $20 \mathrm{~m}$ near the Peruvian coast. The meridional velocity distribution clearly shows that this eddy was separated already from the shelf-break given that near the shelf-break the southward flowing Peru-Chile Undercurrent (PCU) is seen in southeastward flow components (Fig. 5) flowing in the opposite direction as the flow component in the eastern part of the anticyclone, which is directed northward.

High resolution profiles of bottle samples for nutrient determination were only taken east of $76^{\circ} \mathrm{W}$ for this section A2 and represent the near-shelf parameter distribution (Fig. 6, right) which might have influenced the eddy during the formation process. As a function of upwelling intensity the nitrite layer rose near the shelf-break and higher nitrate, phosphate and silicate concentrations were located near the surface. As mentioned the PCU is suspected to create the anticyclonic eddies. At the eastern side of section A2 (Fig. 6) the PCU is seen with eastward and southward flow components. The related salinity, temperature and density fields show similar enlarged values and reduced oxygen values as in the centre of the eddy at $76^{\circ} 30^{\prime} \mathrm{W}$ and indicate water from the PCU in eddy A. However, nitrate, nitrite, phosphate and silicate in the PCU region do not agree with the parameter distribution in the core of eddy $\mathrm{A}$ in section $\mathrm{A} 1$ and hence should have been modified by local processes.

\subsection{The open ocean anticyclonic eddy (eddy B)}

The parameter distribution of the section across the anticyclonic eddy B centred in the open ocean at about $83^{\circ} 50^{\prime} \mathrm{W}$ at $16^{\circ} 45^{\prime} \mathrm{S}$ shows the low oxygen layer extending vertically between 100 and $600 \mathrm{~m}$ depth (Fig. 7). The open ocean anticyclonic eddy was a weak mode water type anticyclone with the change in density anomaly occurring at $300 \mathrm{~m}$ depth. Below 

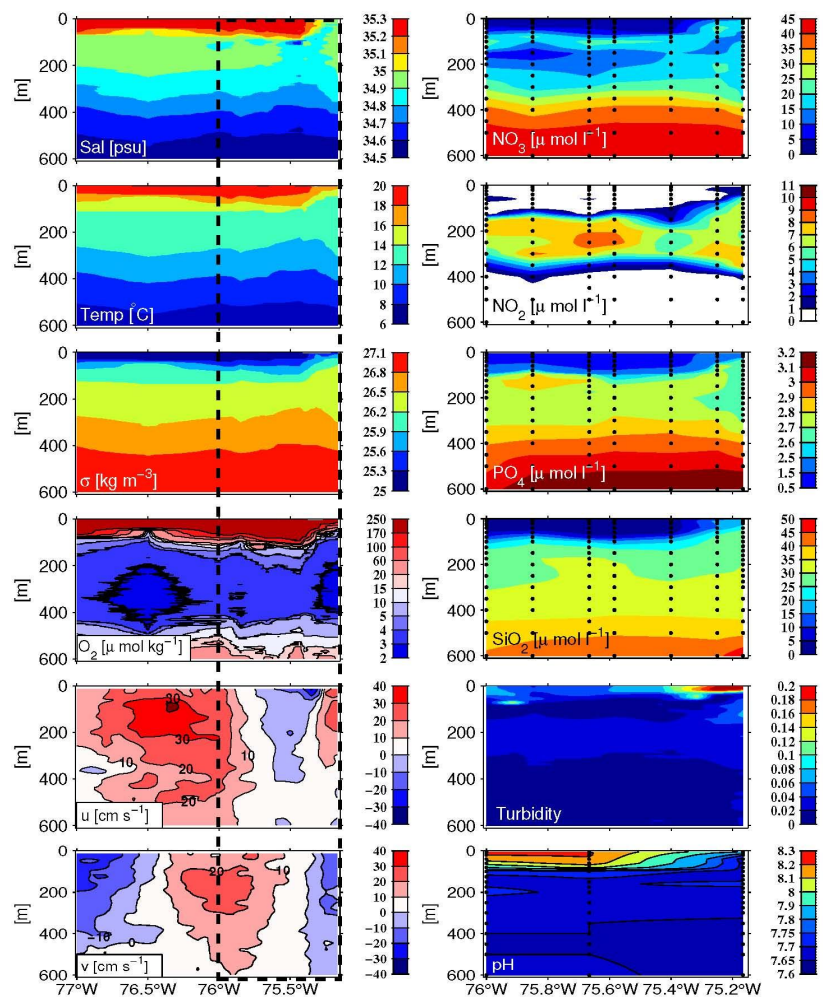

Fig. 6. Parameter distribution in the anticyclonic eddy A, section A2 off the Peruvian shelf from $77^{\circ} \mathrm{W}, 16^{\circ} 45^{\prime} \mathrm{S}$ to $76^{\circ} \mathrm{W}$ along $16^{\circ} 45^{\prime} \mathrm{S}$ and then northeastward to $75^{\circ} 09^{\prime} \mathrm{W}, 15^{\circ} 30^{\prime} \mathrm{S}$ (see Fig. 1) on 22 and 23 November 2012 for salinity, temperature, density, oxygen concentrations and zonal ( $\mathrm{u}$, positive eastward) and meridional (v, positive northward) ADCP velocity components (left) and the eastern part of section A2 only (east of the dashed line in the left frames) as no bottle data were collected between $76^{\circ} \mathrm{W}$ and $77^{\circ} \mathrm{W}$ from $76^{\circ} \mathrm{W}, 16^{\circ} 45^{\prime} \mathrm{S}$ to $75^{\circ} 09^{\prime} \mathrm{W}, 15^{\circ} 30^{\prime} \mathrm{S}$ for concentrations of nitrate, nitrite, phosphate, silicate, turbidity and $\mathrm{pH}$ (right). For bottle data of the nutrient concentrations and $\mathrm{pH}$ the sampling depths are marked by black dots.

$200 \mathrm{~m}$ depth salinity and temperature anomalies were positive and oxygen anomalies were slightly negative. Between $100 \mathrm{~m}$ and $200 \mathrm{~m}$ depth strong negative salinity, temperature and oxygen anomalies are present (Fig. 3). Distinct maxima of phosphate, silicate and nitrate concentration anomalies were located at $120 \mathrm{~m}$ to $150 \mathrm{~m}$ depth. Similar to near-shelf anticyclone A, turbidity was higher in the eddy between $50 \mathrm{~m}$ and $400 \mathrm{~m}$, however, without the enhanced maximum below the mixed layer. The chlorophyll section shows a maximum of 2.5 (cc) $\mu \mathrm{g} \mathrm{L}^{-1}$ in the core of the eddy (Fig. 4) at a $40 \mathrm{~m}$ depth in a layer of weak density stratification and is less than half as in the coastal anticyclone. As the mixed layer reached deeper, enhanced chlorophyll values reach down to about $80 \mathrm{~m}$ depth and hence deeper than for the coastal anticyclone A. The swirl velocity at 200 to $400 \mathrm{~m}$ depth was much weaker than for the coastal anticyclone A. The maxi-

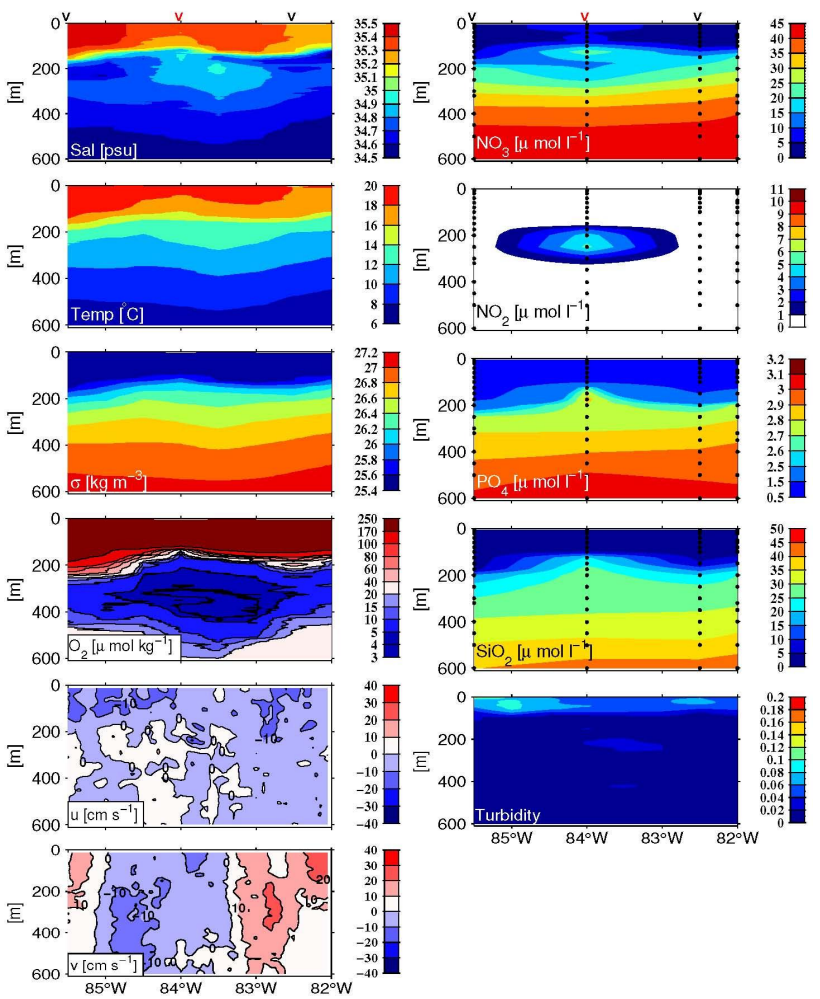

Fig. 7. Parameter distribution in the anticyclonic eddy B centred at about $83^{\circ} 50^{\prime} \mathrm{W}$ along $16^{\circ} 45^{\prime} \mathrm{S}$ between $85^{\circ} 30^{\prime} \mathrm{W}$ and $82^{\circ} \mathrm{W}$ 16 to 18 November 2012 for salinity, temperature, density, oxygen concentration and zonal $(\mathrm{u}$; positive eastward) and meridional $(\mathrm{v}$, positive northward) ADCP velocity components (left) and nitrate, nitrite, phosphate, silicate concentration and turbidity (right). Only on one station $\mathrm{pH}$ samples were taken hence no $\mathrm{pH}$ section can be plotted. For bottle data of the nutrient concentrations the sampling depths are marked by black dots. To compute the eddy core anomalies in Fig. 3 the two outside profiles used are marked on top with a black $\mathrm{v}$ and the core profile with a red $\mathrm{v}$.

mum swirl velocities of $16 \mathrm{~cm} \mathrm{~s}^{-1}$ are about twice as large as for the mean anticyclones (Chaigneau et al., 2011).

In comparison with the coastal anticyclone A, the anomalies observed in the oxygen minimum zone are weaker below about $200 \mathrm{~m}$ depth in the open ocean anticyclone B, especially for temperature and density (Fig. 3). The anomalies below the mixed layer were similar for temperature, oxygen, phosphate and silicate, however located about $100 \mathrm{~m}$ deeper in the open ocean eddy than near the coast.

Following the trajectory of the anticyclone B back in time it was located at $17^{\circ} 45^{\prime} \mathrm{S}, 78^{\circ} 15^{\prime} \mathrm{W}$ on 7 August 2012. Hence, the anticyclone moved $570 \mathrm{~km}$ westward in 100 days corresponding to a westward propagation speed of $6.5 \mathrm{~cm} \mathrm{~s}^{-1}$, which is only slightly faster than the westward movement of the coastal anticyclone A. On 13 June 2012 it was located at $18^{\circ} 15^{\prime} \mathrm{S}, 76^{\circ} 15^{\prime} \mathrm{W}$ and the westward velocity for the 161 days to 21 November was $4.75 \mathrm{~cm} \mathrm{~s}^{-1}$. Before 13 June anticyclonic eddies were located to the northeast and 
southwest and the eddy signal was no longer visible, hence the time and location of formation could not be determined for eddy B. Nevertheless, eddy B was more than 5 months old and hence more than 3 months older than eddy $\mathrm{A}$ at the time of measurements.

\subsection{The cyclonic feature (eddy C)}

Several cyclonic (clockwise rotation in the Southern Hemisphere) features were visible in the region off Peru at the time of the R/V Meteor cruise in November 2012 (Fig. 1b). Along the $16^{\circ} 45^{\prime} \mathrm{S}$ section a large cyclonic eddy (i.e. eddy C) was centred with maximum SSHA at $16^{\circ} 15^{\prime} \mathrm{S}, 80^{\circ} 15^{\prime} \mathrm{W}$ on 21 November 2012 with a strong southwest to northeast extension. A cyclonic feature is located to the south of eddy $\mathrm{C}$ (Fig. 1b) and interacts with the cyclonic feature, hence the southeastern boundary of eddy was defined at $16^{\circ} 55^{\prime} \mathrm{S}$, $80^{\circ} \mathrm{W}$ (Fig. 8).

Cyclones dome for both the mixed layer and the main thermocline as corroborated by a positive density anomaly for the entire $600 \mathrm{~m}$ shown (Figs. 3 and 8 ). The swirl velocity core of cyclones is expected near the surface and the cyclone at $81^{\circ} \mathrm{W}$ accordingly had the largest velocities of about $30 \mathrm{~cm} \mathrm{~s}^{-1}$ at about $50 \mathrm{~m}$ depth. The parameter distribution on the diagonal section $\mathrm{C}$ between $15^{\circ} 10^{\prime} \mathrm{S}$ and $17^{\circ} 30^{\prime} \mathrm{S}$ shows elevated oxygen concentrations in the OMZ centred at $16^{\circ} 20^{\prime} \mathrm{S}, 80^{\circ} 30^{\prime} \mathrm{W}$ corresponding to higher $\mathrm{pH}$ values (Fig. 8). No nitrite was observed in the core of cyclone C, while the nitrite maximum found in the southern part of the section (Fig. 8) originated from a neighbouring anticyclonic eddy located at the southern end of the section (Fig. 1). The temperature, salinity and density anomalies of cyclone $\mathrm{C}$ in the OMZ were of similar strength as those of the coastal anticyclone A, but with opposite sign. The oxygen anomaly of the cyclone $\mathrm{C}$ was even larger in the OMZ than observed for the coastal anticyclone, which is explained by the fact that in the OMZ it is easier to create an anomaly by adding high oxygen waters than to reduce very low oxygen levels further. The silicate anomalies were of opposite sign to the coastal anticyclone A below $150 \mathrm{~m}$ depth.

Below the mixed layer at about $100 \mathrm{~m}$ depth the oxygen anomaly was lowest due to the uplift of the main thermocline, but phosphate and silicate only show weak positive anomalies at about $80 \mathrm{~m}$ and weak negative anomalies at about $130 \mathrm{~m}$ (Fig. 3). A chlorophyll maximum of 2.8 (cc) $\mu \mathrm{g} \mathrm{L}^{-1}$ was located between 20 and $40 \mathrm{~m}$ depth slightly to the north of the core of the cyclonic eddy C. This chlorophyll maximum was higher than that of anticyclone B in the open ocean and showed a higher positive turbidity anomaly in the upper $40 \mathrm{~m}$.

Cyclonic eddy $\mathrm{C}$ appeared for the first time on 1 September 2012 at the coast at $16^{\circ} 15^{\prime} \mathrm{S}, 76^{\circ} \mathrm{W}$ and immediately moved westward without staying attached to the shelf-break. This cyclone reached $16^{\circ} 15^{\prime} \mathrm{S}, 80^{\circ} 15^{\prime} \mathrm{W}$ on 21 November, which corresponds to a westward transit speed of $6.3 \mathrm{~cm} \mathrm{~s}^{-1}$.
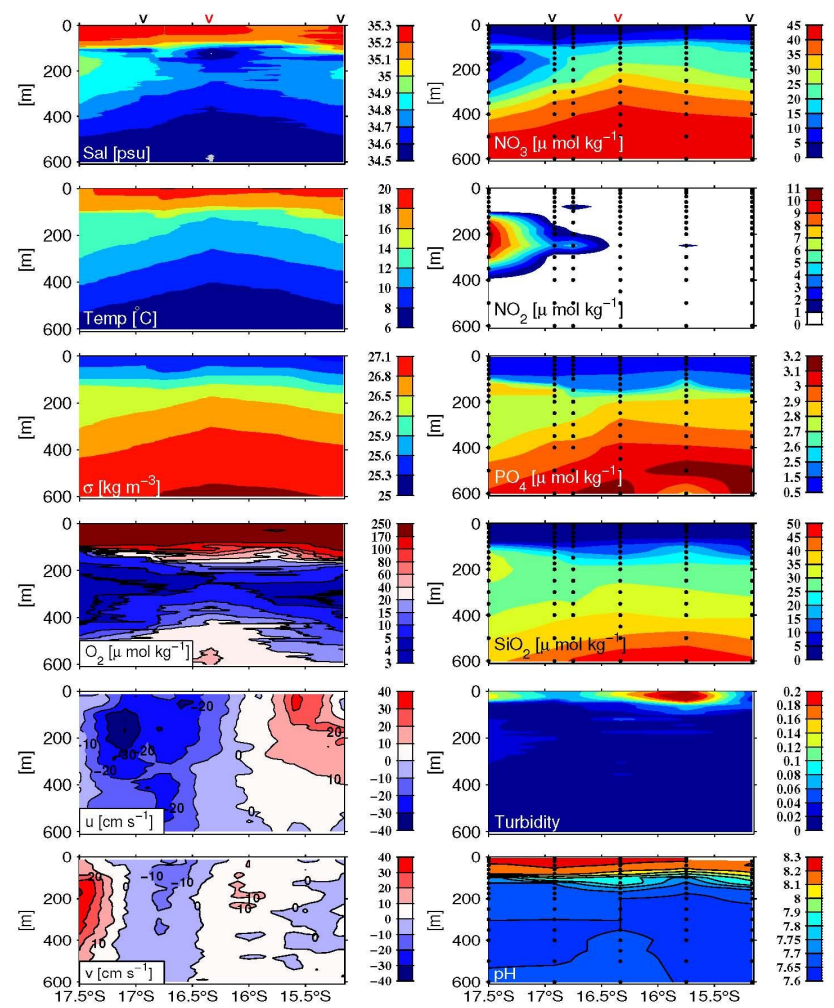

Fig. 8. Parameter distribution in the cyclonic eddy $\mathrm{C}$ on a diagonal section between $17^{\circ} 30^{\prime} \mathrm{E}, 79^{\circ} 30^{\prime} \mathrm{W}$ and $15^{\circ} 10^{\prime} \mathrm{E}, 81^{\circ} 30^{\prime} \mathrm{W}$ (SE to NW, see Fig. 1) on 20 and 21 November 2012 for salinity, temperature, density, oxygen concentration and zonal (u; positive eastward) and meridional (v, positive northward) ADCP velocity components (left) and nitrate, nitrite, phosphate, silicate concentration, turbidity and $\mathrm{pH}$ (right). For bottle data of the nutrient concentrations and $\mathrm{pH}$ the sampling depths are marked by black dots. To compute the eddy core anomalies in Fig. 3 the two outside profiles used are marked on top with a black $\mathrm{v}$ and the core profile with a red $\mathrm{v}$.

As can be seen in the sea level anomaly distribution (Fig. 1b) the cyclonic eddy $\mathrm{C}$ had a wider core and only a weak maximum at $80^{\circ} 25^{\prime} \mathrm{W}$, hence the core of the eddy may have been located further to the west, which would increase the calculated westward transit speed. Tracking the eddy forward in time showed that its core reached $15^{\circ} 30^{\prime} \mathrm{S}, 85^{\circ} \mathrm{W}$ on 13 February 2013 which results in a northwestward velocity of $7.1 \mathrm{~cm} \mathrm{~s}^{-1}$.

\section{5 $\quad \mathrm{N}^{*}$ computations}

$\mathrm{N}^{*}$ (for a definition see the section on observational data) is an indicator for nitrogen sink/source processes in the water column: negative $\mathrm{N}^{*}$ values indicate nitrogen sinks including denitrification, DNRA and anammox, whereas, positive $\mathrm{N}^{*}$ values indicate nitrogen sources such as $\mathrm{N}_{2}$ fixation. The vertical distribution of the $\mathrm{N}^{*}$ anomalies $\left(\Delta \mathrm{N}^{*}\right.$, Fig. 3$)$ shows well defined $\Delta \mathrm{N}^{*}$ minima of about $-35 \mu \mathrm{mol} \mathrm{L}^{-1}$ in $50 \mathrm{~m}$ depth (eddy A) and of about $-20 \mu \mathrm{mol} \mathrm{L}^{-1}$ in $150 \mathrm{~m}$ depth 
(eddy B). Moreover, a second, even broader, $\Delta \mathrm{N}^{*}$ minimum of about $-20 \mu \mathrm{mol} \mathrm{L}^{-1}$ at about $200 \mathrm{~m}$ is visible in eddy A, but there is no second $\Delta \mathrm{N}^{*}$ minimum detectable in eddy $\mathrm{B}$ although $\Delta \mathrm{N}^{*}$ remains slightly negative. Following the arguments of Altabet et al. (2012), the second $\Delta \mathrm{N}^{*}$ minimum in eddy $\mathrm{A}$ and the negative $\Delta \mathrm{N}^{*}$ in eddy $\mathrm{B}$ are attributed to active nitrogen loss processes within eddies of the OMZ. The upper $\Delta \mathrm{N}^{*}$ minimum, which is located above the $\mathrm{OMZ}$, is most probably a residual of the uplifted PCU during its upwelling at the shelf. This is in contrast to the interpretations of Altabet et al. (2012) who argued that the upper $\mathrm{N}^{*}$ minimum observed in a comparable anticyclonic coastal eddy off Peru resulted from shelf waters that had been in contact with shelf sediments and thus were carrying signals of sedimentary dentrification and/or anammox (Altabet et al., 2012).

The decreased $\Delta \mathrm{N}^{*}$ values of eddy B compared to those in eddy A points to a decline of the nitrogen loss processes during aging of mode water eddies on their way from the coast to the open ocean. Alternatively, the lower $\Delta \mathrm{N}^{*}$ in eddy $\mathrm{B}$ might be caused by different initial biogeochemical settings at the time when eddies A and B were formed. In sharp contrast to eddies $\mathrm{A}$ and $\mathrm{B}$, the vertical distribution of $\Delta \mathrm{N}^{*}$ (Fig. 3) of eddy $\mathrm{C}$ shows positive values in the OMZ (150$450 \mathrm{~m}$ ). However, these data cannot be interpreted as being caused by enhanced nitrogen sources but resulted from the fact that $\mathrm{N}^{*}$ at the fringes of the cyclonic eddy $\mathrm{C}$ (see e.g. $\mathrm{NO}_{2}^{-}$distribution in Fig. 8), which are influenced by an adjacent, anticyclonic eddy, were more negative than those in the core of eddy $\mathrm{C}$.

\section{Discussion}

As the ETSP is covered by cyclonic and anticyclonic features (Fig. 1b) and by variability, e.g. El Nino phases, it is difficult to derive a mean background field. Nevertheless, a comparison of our sections with the mean climatology of the World Ocean Database showed small salinity deviations in the region, where we defined the boundaries of our eddies. A comparison of the salinity profiles shows up to 0.25 higher salinities in the centre of the anticyclonic eddies A and B than for the eastern rim stations of these two eddies (Fig. 9). The comparison with the salinity of the profile at the PCU location in section A2 shows that the salinity in the centres of the anticyclonic eddies below $120 \mathrm{~m}$ is similar high, however, with deviations of up to 0.1 . In the upper $100 \mathrm{~m}$ the salinity of all profiles is higher than at the PCU location, probably related to the near-shelf upwelling. Nevertheless, the similar salinity in the anticyclonic eddy centres and the lower salinity at the rim stations show, that the eddies carry water from the PCU area westward. Differences in the salinity profiles might be related to water mass differences in the eddy formation area. The cyclonic eddy shows lower salinities at most depth compared to the rim stations (Fig. 9) and confirms the transport of low salinity in its centre.

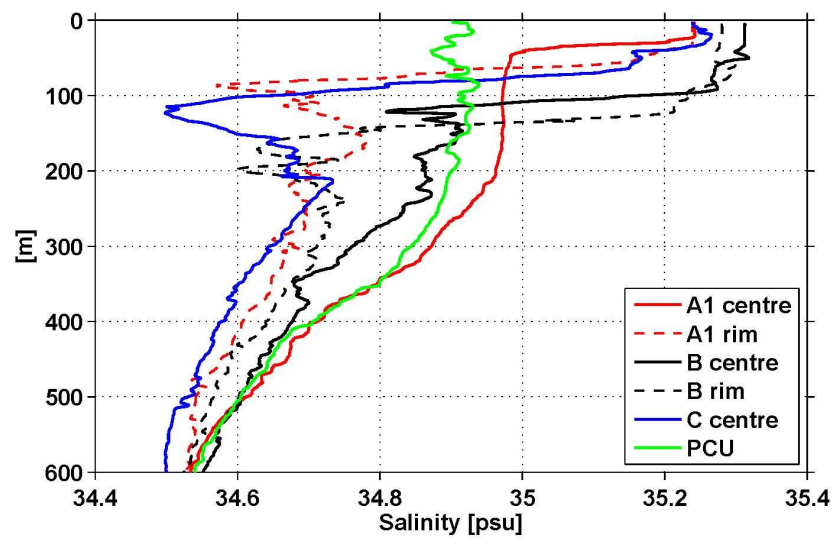

Fig. 9. Salinity profiles at the PCU location of section A2 (green line), the core of the centre of eddy A in section A1 (red line), the centre of the eddy B (black line), the centre of eddy C (blue line) and the eastern rim stations of section $\mathrm{A} 1$ (dashed red line) and of eddy B (black dashed line).

The depth distributions of the temperature and salinity anomalies based on detailed CTD sections and the swirl velocity derived from the ADCP measurements of the eddies $\mathrm{A}-\mathrm{C}$ are in agreement with the mean fields derived from float profiles (Chaigneau et al., 2011). The anticyclone A off the shelf-break showed a temperature increase of $2{ }^{\circ} \mathrm{C}$ and a salinity increase of 0.2 in its core (Fig. 3), which is about twice as large as that of mean anticyclones in the eastern tropical South Pacific (Chaigneau et al., 2011). Also the observed swirl velocity of up to $35 \mathrm{~cm} \mathrm{~s}^{-1}$ is more than twice and up to three times as high as for the mean anticyclones.

The vertical extent of the eddy is defined where the swirl velocity or rotational speed is larger than the translation speed $(U / c>1)$. For the mean anticyclonic eddies between $10^{\circ} \mathrm{S}$ and $20^{\circ} \mathrm{S}$ the vertical extent was $450 \mathrm{~m}$ (Chaigneau et al., 2011). The two anticyclonic eddies A and B had a vertical extent of more than $600 \mathrm{~m}$, however, we carried out the anomaly computation to $600 \mathrm{~m}$ depth only (Table 1 ). The volume of anticyclone A was $5.2 \times 10^{12} \mathrm{~m}^{3}$, similar to the volume of $4.9 \times 10^{12} \mathrm{~m}^{3}$ of the mean anticyclone. However, the AHA of $17.7 \times 10^{18} \mathrm{~J}$ and the ASA of $36.5 \times 10^{10} \mathrm{~kg}$ are a factor 2.7 and 2.1 larger than for the mean anticyclone, respectively, based on their larger vertical extent and higher temperature and salt anomalies.

Salinity and temperature decreased in eddy B by 0.3 and up to $2{ }^{\circ} \mathrm{C}$, respectively, which is again about twice as much as that of the mean cyclones (Chaigneau et al., 2011; Fig. 5), as well as of a cyclonic eddy measured in November 2008 in the eastern Pacific Ocean (Subramanian et al., 2013). Although the vertical extent of eddy B of more than $600 \mathrm{~m}$ was again larger than that of the mean eddy (Table 1) the volume of $4.7 \times 10^{12} \mathrm{~m}^{3}$ was slightly less than that of the mean eddy as the radius defined between the maxima in swirl velocities was a little smaller. The AHA was only half of the mean 
Table 1. Anomalies of mean anticyclonic (AE) and cyclonic (CE) eddies computed for the region $10^{\circ} \mathrm{S}$ to $20^{\circ} \mathrm{S}$ (Chaigneau et al., 2011) and for the 3 eddies A, B and C to a depth of $600 \mathrm{~m}$ although the vertical extent is even larger. Available heat anomaly (AHA) and available salt anomaly (ASA) within one eddy are computed following Chaigneau et al. (2011).

\begin{tabular}{lrrrrr}
\hline & Chaigneau et al. & A & B & C \\
& \multicolumn{2}{c}{$(2011)$} & & & \\
\hline & $($ AE) & $(\mathrm{CE})$ & $(\mathrm{AE})$ & $(\mathrm{AE})$ & $(\mathrm{CE})$ \\
Vertical extent $(\mathrm{m})$ & $0-450$ & $0-200$ & $0-600$ & $0-600$ & $0-600$ \\
Radius $(\mathrm{km})$ & 57.6 & 62.3 & 52.0 & 48.8 & 88.0 \\
Volume $\left(\times 10^{12} \mathrm{~m}^{3}\right)$ & 4.9 & 2.6 & 5.2 & 4.7 & 14.8 \\
AHA $\left(\times 10^{18} \mathrm{~J}\right)$ & 6.5 & -5.9 & 17.7 & 3.7 & -49.8 \\
ASA $\left(\times 10^{10} \mathrm{~kg}\right)$ & 17.4 & -14.7 & 36.5 & 18.7 & -98.8 \\
\hline
\end{tabular}

anticyclonic eddy as the temperature anomaly was negative in the upper $200 \mathrm{~m}$ for the mode water type eddy while the ASA was similar to the mean anticyclone.

While the vertical extent of the mean cyclonic eddy was only $200 \mathrm{~m}$, that of eddy $\mathrm{C}$ reached again deeper to $950 \mathrm{~m}$ depth (not shown) and also the radius of $88 \mathrm{~km}$ was much larger than the $62.3 \mathrm{~km}$ for the mean cyclonic eddy (Table 1). Therefore, the AHA of eddy $\mathrm{C}$ for the upper $600 \mathrm{~m}$ was 8.4 times and the ASA 6.7 times larger than for the mean cyclonic eddy. However, the cyclonic feature $\mathrm{C}$ is quite unusual given its elongated shape and should not be considered the typical cyclonic eddy.

Large temperature and salinity anomalies and the swirl velocity obtained from our in-situ measurements along $16^{\circ} 45^{\prime} \mathrm{S}$ are up to $2{ }^{\circ} \mathrm{C}$ warmer, 0.3 more saltier and more than twice as large (up to $35 \mathrm{~cm} \mathrm{~s}^{-1}$ ), respectively, as those computed for the mean eastern South Pacific eddies (Chaigneau et al., 2011). As both methods differ, e.g. in the definition of the eddy boundaries either from real observations restricted to the location of measured profiles or from float profiles related to a climatological mean in relation to satellite data it is not surprising, that different approaches lead to different results. The two methods are based on the data available and both methods are useful despite their differences as long as the method applied is described. The large temperature and salinity anomalies might be caused by using the actual measured values instead of a climatology as reference for the parameter distribution outside of the eddies as used by Chaigneau et al. (2011). The lower swirl velocity computed by Chaigneau et al. (2011) is caused by their assumption of a level of zero geostrophic velocity at $1000 \mathrm{~m}$ depth for the mean distribution while in our study the deep reaching measurements using the $38 \mathrm{kHz}$ ADCP which included also non-geostrophic velocity components showed a swirl component of $7.5 \mathrm{~cm} \mathrm{~s}^{-1}$ for eddy A, $7.7 \mathrm{~cm} \mathrm{~s}^{-1}$ for eddy $\mathrm{B}$ and $6.8 \mathrm{~cm} \mathrm{~s}^{-1}$ for eddy $\mathrm{C}$ at $1000 \mathrm{~m}$ depth.

After its formation on 14 September 2012 anticyclonic eddy A moved slowly westward for 1.5 months with $2.6 \mathrm{~cm} \mathrm{~s}^{-1}$ and then stayed off the shelf-break for about 2 months before it began to move westward in mid-December 2012. The estimated westward transit speeds for the eddies $\mathrm{A}-\mathrm{C}$ were in the range from $4.75 \mathrm{~cm} \mathrm{~s}^{-1}$ (eddy B) to $7.1 \mathrm{~cm} \mathrm{~s}^{-1}$ (eddy C). Hence they are only slightly higher than the mean westward eddy propagation speed of $3-6 \mathrm{~cm} \mathrm{~s}^{-1}$ computed for the region off Peru (Chaigneau et al., 2008). The slightly higher transit speed is probably due to the fact that our measurements in the northern reaches of the westward flowing subtropical gyre (Kessler, 2006).

We observed pronounced maxima and minima for the majority of the hydrographic (temperature, salinity, density) and biogeochemical (nutrients, oxygen, turbidity, $\mathrm{pH}$ ) anomalies in $50 \mathrm{~m}$ and $150 \mathrm{~m}$ depth of the coastal eddy $\mathrm{A}$ and the open ocean eddy B, respectively (Fig. 3). These characteristic anomalies most likely originated from the nutrientenriched/oxygen-depleted PCU which flows poleward in a depth range from 50 to $350 \mathrm{~m}$ and which prevails at distances between 65 and $165 \mathrm{~km}$ from the Peruvian coast (Huyer et al., 1991). The PCU fuels the coastal upwelling of Peru (Brink et al., 1983; Huyer et al., 1991). During the winddriven upwelling the waters of the PCU are brought to the surface at the shelf (Fig. 6). However, the uplifted nutrientrich/oxygen-depleted water of the PCU was trapped in upper part of eddy A when it was detached from the shelf-break. Obviously the anomalies are generally subducted to $150 \mathrm{~m}$ when an eddy is moving westward as can be seen for eddy B (Fig. 3). The generally less pronounced anomalies of eddy $\mathrm{B}$ (compared to eddy A) result from a different initial setting when eddy $\mathrm{B}$ was formed. The $\mathrm{NO}_{3}^{-}$anomaly does not show a maximum at $50 \mathrm{~m}$ (eddy $\mathrm{A}$ ) or $150 \mathrm{~m}$ depth (eddy B). This is caused by the fact that the trapped PCU is enriched in nutrients except $\mathrm{NO}_{3}^{-}$because in low oxygen waters denitrification and/or DNRA lead to a decrease of $\mathrm{NO}_{3}^{-}$concentrations. The pronounced subsurface chlorophyll maxima in the eddies A-C that were found in a depth range from $30 \mathrm{~m}$ (eddy C) to $50 \mathrm{~m}$ (eddy A, Fig. 4), are a typical feature of both cyclonic and mode water eddies, which is caused by eddy pumping of nutrients into the euphotic zone (see e.g. McGillicuddy Jr. et al., 1998, 2007). The eddy pumping results from the uplift of the isopycnals in the core of eddies A-C (see Figs. 2, 7 and 8). Comparison of the chlorophyll maxima of the "young" coastal eddy A and the "older" open ocean eddies B and C reveals that the chlorophyll concentrations in the subsurface maxima are significantly lower in the eddies $\mathrm{B}$ and $\mathrm{C}$ most probably because of the decline of nutrients in the euphotic zone while the eddies were moving westward. The chlorophyll distribution in eddy B shows widespread slightly enhanced and deeper reaching concentrations compared to the eddy A. The westward deepening of the chlorophyll layer was described e.g. for a section off Chile in late 2004 (Claustre et al., 2008). The slightly higher chlorophyll concentrations might be related to different phytoplankton communities active in the different areas, 
but no phytoplankton measurements were made during the cruise.

The chlorophyll concentrations of the subsurface maximum in eddy A are in the same concentration range as the chlorophyll concentrations in the surface layer of the coastal upwelling (see section A2 in Fig. 4). Assuming that chlorophyll concentrations can be taken as a (qualitative) indicator for primary productivity this finding suggests that eddies may play an important role for the overall productivity off Peru. Additionally, the development of a pronounced filament structure at the northern fringe of eddy A (which is clearly visible in the satellite picture, see Fig. 5) documents that due to the rotation of the eddy, highly productive surface waters are transported westward far beyond the narrow band of coastal upwelling at the shelf. However, there is large uncertainty involved with regard to biogeochemical significance of eddies given the small number of observations.

Both the vertical concentration distributions (Fig. 2), as well as the anomalies (Fig. 3) of oxygen and nutrients (i.e. nitrate, nitrite) in mode water eddy A reveal a core layer where pronounced loss of fixed nitrogen occurs. This is indicated by the pronounced maximum of $\mathrm{NO}_{2}^{-}$concentrations (often also referred to as the secondary nitrite maximum, SNM) at about $250-300 \mathrm{~m}$ depth, which is associated with the pronounced minima of both $\mathrm{O}_{2}(<5 \mu \mathrm{mol} \mathrm{L}-1)$ and $\mathrm{NO}_{3}^{-}$ concentrations between 100 and $300 \mathrm{~m}$ depth. Please note that the OMZ (here defined as $\mathrm{O}_{2}<20 \mu \mathrm{mol} \mathrm{L}^{-1}$ ) spreads from 100 to $600 \mathrm{~m}$ depth. The co-occurrence of extremely depleted $\mathrm{O}_{2}$ and $\mathrm{NO}_{3}^{-}$, coinciding with high $\mathrm{NO}_{2}^{-}$concentrations have been attributed to on-going denitrification (Fiadeiro and Strickland, 1968; Codispoti et al., 1986) or DNRA (Lam et al., 2009). Enhanced turbidity as a measure for suspended material and particles, is also found between 100 and $300 \mathrm{~m}$ in eddy A (Figs. 2 and 6) which indicates the existence of an intermediate nepheloid layer known to be associated with enhanced microbial activity. These layers are, moreover, known to play important roles in other OMZs adjacent to coastal upwelling regions such as the Arabian Sea and off NW Africa (Naqvi et al., 1993; Fischer et al., 2009).

A similar feature is seen in the $\mathrm{O}_{2}$ and $\mathrm{NO}_{2}^{-} / \mathrm{NO}_{3}^{-}$distributions and anomalies (Figs. 3 and 7) of the mode water eddy $\mathrm{B}$. The $\mathrm{NO}_{3}^{-}$concentrations in the "aged" eddy $\mathrm{B}$ are, however, higher compared to the "young" eddy A. This apparent contradiction (the older an eddy the more $\mathrm{NO}_{3}^{-}$should have been lost due to the ongoing $\mathrm{N}$ loss processes) is most probably resulting from higher initial $\mathrm{NO}_{3}^{-}$concentrations at the time of formation of eddy $\mathrm{B}$. The maximum concentration of $\mathrm{NO}_{2}^{-}$of up to $5 \mu \mathrm{mol} \mathrm{L} \mathrm{L}^{-1}$ measured in eddy $\mathrm{B}$ is significantly lower than that of up to $11 \mu \mathrm{mol} \mathrm{L}{ }^{-1}$ measured in eddy A. This points to a significantly lower activity of nitrogen loss processes in eddy $\mathrm{B}$. The $\mathrm{NO}_{2}^{-}$concentrations measured during our cruise in November 2012 are in the same range as those reported in previous studies of the SNM in the OMZ off Peru (see, for example, Barber and Huyer, 1979; Copin-
Montégut and Raimbault, 1994; Fernández et al., 2009; Altabet et al., 2012; Casciotti et al., 2013) but lower than the exceptionally high $\mathrm{NO}_{2}^{-}$concentrations (up to $23 \mu \mathrm{mol} \mathrm{L}-1$ in February/March 1985) reported by Codispoti et al. (1986).

In contrast to the mode water eddies $\mathrm{A}$ and $\mathrm{B}$, the core of cyclonic eddy $\mathrm{C}$ shows a compression of the OMZ to a narrow band between $150-450 \mathrm{~m}$ where no loss of $\mathrm{NO}_{3}^{-}$and no enhanced $\mathrm{NO}_{2}^{-}$concentrations have been measured. Signs of nitrogen loss processes in eddy $\mathrm{C}$ are only visible at the southern fringe at about $17^{\circ} \mathrm{S}$ (Fig. 8) which are caused by an adjacent anticyclonic eddy (Fig. 1). Thus, we conclude that in eddy $\mathrm{C}$ active nitrogen loss processes were negligible at the time of our measurements.

Recently, concern has emerged that $\mathrm{CO}_{2}$-driven climate change results in decreasing dissolved oxygen (DO) levels in the ocean (e.g. Keeling and Garcia, 2002; Bopp et al., 2002) with potentially large impacts on marine habitats and ecosystems (Keeling et al., 2010; Stramma et al., 2012b). Continuous time series in a few selected tropical areas with sufficient data (Stramma et al., 2008), as well as comparison between two distinct time periods in the tropical oceans (Stramma et al., 2010a), and observed changes at $300 \mathrm{dbar}$ for the entire ocean over the past $50 \mathrm{yr}$ (Stramma et al., 2012a) indicate an ongoing decline of oxygen and a vertical expansion of the OMZ in most tropical regions, contrasted by areas dominated by DO increase, predominantly in the subtropical gyres. However, Chaigneau et al. (2009) computed a decreasing trend for the number of generated eddies off Peru and Chile in the period 1995-2007. Assuming that this trend is continuing, we speculate that a decreasing number of eddies might lead to an increase of oxygen concentrations in the OMZ off Peru: A decreasing eddy-fueled productivity will lead to a decreasing transport of organic material to the open ocean which, in turn, decreases the demand of oxygen for respiration. Decreasing numbers of eddies might also influence the number of nitrogen loss hotspots, thus the total nitrogen loss from the ETSP might be decreasing in the future if the decreasing trend in numbers of eddies will continue.

Fundamental to a realistic prediction of changing future OMZs are, however, accurate determinations of oxygen distributions, processes maintaining the $\mathrm{OMZ}$, and dynamics of the OMZ, of which eddies may be one of the most important components.

\section{Conclusions}

Two mode water eddies and one cyclonic eddy (see eddies A-C in Fig. 1) were investigated in detail along a cruise track at $16^{\circ} 45^{\prime} \mathrm{S}$ off Peru in November 2012 in order to determine both the hydrographic properties and the influence of eddies on the biogeochemical cycling of the ETSP. The motivation of this study arose from the fact that detailed information on the oxygen and nutrient anomalies in eddies had 
not been reported previously for the eastern tropical South Pacific Ocean.

In the thermocline the temperature of the coastal anticyclonic eddy was up to $2{ }^{\circ} \mathrm{C}$ warmer, 0.2 saltier and the swirl velocity was up to $35 \mathrm{~cm} \mathrm{~s}^{-1}$. The observed temperature, salinity anomalies and swirl velocities of both types of eddies were about twice as large as had been described for the mean eddies in the ETSP. The AHA and ASA estimates for the upper $600 \mathrm{~m}$ showed that eddies are quite variable leading to large deviations from the mean state. The vertical extent of the mean eddies might be biased to low values due to the chosen zero geostrophic reference velocity at $1000 \mathrm{~m}$ depth, which contrasts with our direct ADCP measurements documenting the eddy swirl velocity to reach deeper than $1000 \mathrm{~m}$ at values of about $7 \mathrm{~cm} \mathrm{~s}^{-1}$ at $1000 \mathrm{~m}$ depth. The differences derived for the eddies might be biased to low values if the section does not cross the centre, however as AHA and ASA are high compared to the mean values, the sections used are expected to be located close to the centre.

Based on our data, we conclude that young coastal eddies contribute to the productivity off Peru by the development of productivity maxima in the subsurface, which are fueled by nutrient-rich upwelled waters originating from the PCU trapped in coastal eddies. However, the subsurface productivity decreases when both mode water and cyclonic eddies are detached from the coast and move westward. The aging of the mode water eddies is associated with a significant subduction of nutrients within the eddies from 50 to $150 \mathrm{~m}$ which suggests that mode water eddies may reduce the adjacent open ocean productivity off Peru. This finding supports the model results of Gruber et al. (2011). In the core of the coastal mode water eddy pronounced and active nitrogen loss took place. However, the nitrogen loss was considerably lower in the older, open ocean mode water eddy. Moreover, the surveyed open ocean cyclonic eddy did not show any significant active nitrogen loss. Thus, we conclude that coastal mode water eddies are indeed a "hotspot" of nitrogen loss off Peru as proposed by Altabet et al. (2012). However, the open ocean mode water eddy and the cyclonic eddy seem to be of reduced importance or even negligible, respectively, as hotspots of active nitrogen loss. This may be caused by the reduced flux of organic matter, as indicated by the decrease of the chlorophyll maxima in the open ocean eddies and/or different initial settings at the time of formation.

Additional sub-mesoscale (few $\mathrm{km}$ ) processes might influence the parameter distribution, production and subduction of phytoplankton (e.g. Levy et al., 2001) and the intensification of ocean fronts by down-front winds (Thomas and Lee, 2005), which we did not resolve with our dataset. Lapeyre and Klein (2006) showed that intermittent events, such as encounters of an eddy with stronger dipole, produce a very large number of small-scale filaments that trigger intense vertical pumping. Our results indicate that eddies play an important role for the hydrographic setting and biogeochemical cycling of the ETSP. Therefore, the comparably small scale temporal and spatial variability associated with both eddies and sub-mesoscale processes should be taken into account in future oceanographic/biogeochemical studies in the ETSP and other OMZ/coastal upwelling regions.

Acknowledgements. The Deutsche Forschungsgemeinschaft (DFG) provided support as part of the "Sonderforschungsbereich 754: Climate-Biogeochemistry Interactions in the Tropical Ocean" (LS, HWB, RC, MF). Additional support was provided through the Instituto del Mar del Perú, IMARPE (AL). We thank G. Krahmann, T. Fischer, M. Lohmann and T. Baustian for providing measurements and final processing of the various datasets presented. The altimeter data were produced by Ssalto/Duacs and distributed by Aviso with support from Cnes. Analyses and visualisations of chlorophyll used in this study were produced with the Giovanni online data system, developed and maintained by the NASA GES DISC. We also acknowledge the MODIS mission scientists and associated NASA personnel for the production of the data used in this research effort. We thank two anonymous reviewers for their comments which helped to improve the manuscript. We thank the authorities of Peru for the permission to work in their territorial waters.

The service charges for this open access publication have been covered by a Research Centre of the Helmholtz Association.

Edited by: E. Marañón

\section{References}

Altabet, M. A., Ryabenko, E., Stramma, L., Wallace, D. W. R., Frank, M., Grasse, P., and Lavik, G.: An eddy-stimulated hotspot for fixed nitrogen-loss from the Peru oxygen minimum zone, Biogeosciences, 9, 4897-4908, doi:10.5194/bg-9-48972012, 2012.

Barber, R. T. and Huyer, A.: Nitrite and static stability in the coastal waters off Peru, Geophys. Res. Lett., 6, 409-412, 1979.

Bopp, L., Le Quere, C., Heimann, M., Manning, A. C., and Monfray, P.: Climate induced oceanic fluxes: implications for the contemporary carbon budget, Global Biogeochem. Cy., 16, 1022, doi:10.1029/2001GB001445, 2002.

Brink, K. F., Halpern, D., Huyer, A., and Smith, R. L.: The physical environment of the Peruvian upwelling g system, Prog. Oceanogr., 12, 285-305, 1983.

Casciotti, K. L., Buchwald, C., and McIlvin, M.: Implications of nitrate and nitrite isotopic measurements for the mechanisms of nitrogen cycling in the Peru oxygen deficient zone, Deep-Sea Res. Pt. I, 80, 78-93, 2013.

Chaigneau, A., Gizolme, A., and Grados, C.: Mesoscale eddies off Peru in altimeter records: Identification algorithms and eddy spatio-temporal patterns, Prog. Oceanogr., 79, 106-119, 2008.

Chaigneau, A., Eldin, G., and Dewitte, B.: Eddy activity in the four major upwelling systems from satellite altimetry (1992-2007), Prog. Oceanogr., 83, 117-123, doi:10.1016/j.pocean.2009.07.012, 2009. 
Chaigneau, A., Le Texier, M., Eldin, G., Grados, C., and Pizarro, O.: Vertical structure of mesoscale eddies in the eastern South Pacific Ocean: A composite analysis from altimetry and Argo profiling floats, J. Geophys. Res., 116, C11025, doi:10.1029/2011JC007134, 2011.

Chavez, F. P. and Messie, M.: A comparison of eastern upwelling boundary upwelling systems, Prog. Oceanogr., 83, 80-96, 2009.

Chelton, D. B., Schlax, M. G., Samelson, R. M., and de Szoeke, R. A.: Global observations of large oceanic eddies, Geophys. Res. Lett., 34, L15606, doi:10.1029/2007GL030812, 2007.

Chelton, D. B., Gaube, P., Schlax, M. G., Early, J. J., and Samelson, R. M.: The influence of nonlinear mesoscale eddies on nearsurface oceanic chlorophyll, Science, 334, 328-332, 2011.

Claustre, H., Sciandra, A., and Vaulot, D.: Introduction to the special section bio-optical and biogeochemical conditions in the South East Pacific in late 2004: the BIOSOPE program, Biogeosciences, 5, 679-691, doi:10.5194/bg-5-679-2008, 2008.

Codispoti, L. A.: An oceanic fixed nitrogen sink exceeding $400 \mathrm{Tg} \mathrm{N} \mathrm{a}^{-1}$ vs the concept of homeostasis in the fixed-nitrogen inventory, Biogeosciences, 4, 233-253, doi:10.5194/bg-4-2332007, 2007.

Codispoti, L. A., Friederich, G. E., Packard, T. T., Glover, H. E., Kelly, P. J., Spinrad, R. W., Barber, R. T., Elkins, J. W., Ward, B. B., Lipschultz, F., and Lostaunau, N.: High nitrite levels off northern Peru: A signal of instability in the marine denitrification rate, Science, 233, 1200-1202, doi:10.1126/science.233.4769.1200, 1986.

Copin-Montegut, C. and Raimbault, P.: The Peruvian upwelling near $15^{\circ} \mathrm{S}$ in August 1986. Results of continuous measurements of physical and chemical properties between 0 and $200 \mathrm{~m}$ depth, Deep Sea Res. Pt. I, 41, 439-467, 1994.

Correa-Ramirez, M. A., Hormazabel, S. E., and Morales, C. E.: Spatial patterns of annual and interannual surface chlorophyll a variability in the Peru-Chile Current system, Prog. Oceanogr., 92-95, 8-17, 2012.

Czeschel, R., Stramma, L., Schwarzkopf, F. U., Giese, B. J., Funk, A., and Karstensen, J.: Middepth circulation of the eastern tropical South Pacific and its link to the oxygen minimum zone, J. Geophys. Res., 116, C01015, doi:10.1029/2010JC006565, 2011.

Czeschel, R., Stramma, L., and Johnson, G. C.: Oxygen decreases and variability in the eastern equatorial Pacific, J. Geophys. Res., 117, C11019, doi:10.1029/2012JC008043, 2012.

Doney, S. C.: The growing human footprint on coastal and openocean biogeochemistry, Science, 328, 1512-1516, 2010.

Feely, R. A., Sabine, C. L., Hernandez-Ayon, J. M., Ianson, D., and Hales, B.: Evidence for upwelling of corrosive "acidified" water onto the continental shelf, Science, 320, 1490-1492, 2008.

Fernández, C., Farias, L., and Alcaman, M. E.: Primary production and nitrogen regeneration processes in surface waters of the Peruvian upwelling system, Prog. Oceanogr., 83, 159-168, 2009.

Fiadeiro, M. and Strickland, J. D. H.: Nitrate reduction and the occurrence of a deep nitrite maximum in the ocean of the west coast of South America, J. Mar. Res., 26, 187-201, 1968.

Fischer, G., Reuter, C., Karakas, G., Nowald, N., and Wefer, G.: Offshore advection of particles within the Cape Blanc filament, Mauritania: Results from observational and modelling studies, Prog. Oceanogr., 83, 322-330, doi:10.1016/j.pocean.2009.07.023, 2009.
Flierl, G. R.: Particle motions in large-amplitude wave fields, Geophys. Astro. Fluid, 18, 39-74, 1981.

Gruber, N.: The marine nitrogen cycle: overview and challenges, in: Nitrogen in the Marine Environment, edited by: Capone, D. G., Bronk, D. A., Mulholland, M. R., and Carpenter, E. J., Elsevier, Amsterdam, 1-50, 2008.

Gruber, N., Lachkar, Z., Frenzel, H., Marchesiello, P., Münnich, M., McWilliams, J. C., Nagai, T., and Plattner, G.-P.: Eddy-induced reduction of biological production in eastern boundary upwelling systems, Nat. Geosci., 4, 787-792, doi:10.1038/NGEO1273, 2011.

Hansen, H. P.: Determination of oxygen, in: Methods of Seawater analysis, edited by: Grasshoff, K. K., Ehrhardt, M., Wiley-VCH, Weinheim, 75-89, 1999.

Holte, J., Straneo, F., Moffat, C., Weller, R., and Farrar, J. T.: Structure and surface properties of eddies in the southeast Pacific Ocean, J. Geophys. Res., 118, 1-15, doi:10.1002/jgrc.20175, 2013.

Huyer, A., Paluszkiewic, K. M. T., and Smith, R. L.: The Peru Undercurrent: a study in variability, Deep-Sea Res., 38, Suppl. 1, 247-271, 1991.

Karstensen, J., Stramma, L., and Visbeck, M.: Oxygen minimum zones in the eastern tropical Atlantic and Pacific oceans, Prog. Oceanogr., 77, 331-350, 2008.

Keeling, R. F. and Garcia, H.: The change in oceanic $\mathrm{O}_{2}$ inventory associated with recent global warming, P. Natl. Acad. Sci. USA, 99, 7848-7853, 2002.

Keeling, R. F., Körtzinger, A., and Gruber, N.: Ocean deoxygenation in a warming world, Annu. Rev. Mar. Sci., 2, 199-229, 2010.

Kessler, W. S.: The circulation of the eastern tropical Pacific: a review, Prog. Oceanogr., 89, 181-217, doi:10.1016/j.pocean.2006.03.009, 2006.

Klein, P. and Lapeyre, G.: The oceanic vertical pump induced by mesoscale and submesoscale turbulence, Annu. Rev. Mar. Sci., 1, 351-375, 2009.

Lam, P., Lavik, G., Jenssen, M. M., Van de Vossenberg, J., Schmid, M., Woebken, D., Gutierrez, D., Amann, R., Jetten, M. S. M., and Kuypers, M. M. M.: Revising the nitrogen cycle in the Peruvian oxygen minimum zone, P. Nat. Acad. Sci. USA, 106, 4752-4757, 2009.

Lapeyre, G. and Klein, P.: Impact of the small-scale elongated filaments on the oceanic vertical pump, J. Mar. Res., 64, 835-851, 2006.

Levy, M., Klein, P., and Treguier, A.-M.: Impact of sub-mesoscale physics on production and subduction of phytoplankton in an oligotrophic regime, J. Mar. Res., 59, 535-565, 2001.

Mahadevan, A. and Archer, D.: Modeling the impact of fronts and mesoscale circulation on the nutrient supply and biogeochemistry of the upper ocean, J. Geophys. Res., 105, 1209-1225, 2000.

McGillicuddy Jr., D. J., Robinson, A. R., Siegel, D. A., Jannasch, H. W., Johnson, R., Dickey, T. D., McNeil, J., Michaels, A. F., and Knap, A. H.: Influence of mesoscale eddies on new production in the Sargasso Sea, Nature, 394, 263-266, 1998.

McGillicuddy Jr., D. J., Anderson, L. A., Bates, N. R., Bibby, T., Buesseler, K. O., Carlson, C. A., Davis, C. S., Ewart, C., Falkowski, P. G., Goldthwait, S. A., Hansell, D. A., Jenkins, W. J., Johnson, R., Kosnyrev, V. K., Ledwell, J. R., Li, Q. P., Siegel, D. A., and Steinberg, D. K.: Eddy/wind interactions stimulate 
extraordinary mid-ocean plankton blooms, Science, 316, 10211026, 2007.

Morales, C. E., Hormazabel, S., Correa-Ramirez, M., Pizarro, O., Silva, N., Fernandez, C., Anabalon, V., and Torreblanco, M. L.: Mesoscale variability and nutrient-phytoplankton distribution off central-southern Chile during the upwelling season: The influence of mesoscale eddies, Prog. Oceanogr., 104, 17-29, 2012.

Naqvi, S. W. A., Dileep Kumar, M., Narvekar, P. V., De Sousa, S. N., George, M. D., and DeSilva, D.: An intermediate nepheloid layer associated with high microbial metabolic rates and denitrification in the northwestern Indian Ocean, J. Geophys. Res., 98, 16469$16479,1993$.

Oschlies, A. and Garcon, V.: Eddy-induced enhancement of primary production in a model of the North Atlantic Ocean, Nature, 394, 266-269, 1998.

Paulmier, A. and Ruiz-Pino, D.: Oxygen minimum zones (OMZs) in the modern ocean, Prog. Oceanogr., 80, 113-128, 2009.

Stramma, L., Johnson, G. C., Sprintall, J., and Mohrholz, V.: Expanding oxygen-minimum zones in the tropical oceans, Science, 320, 655-658, 2008.

Stramma, L., Schmidtko, S., Levin, L. A., and Johnson, G. C.: Ocean oxygen minima expansions and their biological impacts, Deep-Sea Res. Part I, 57, 587-595, 2010a.

Stramma, L., Johnson, G. C., Firing, E., and Schmidtko, S.: Eastern Pacific oxygen minimum zones: Supply paths and multidecadal changes, J. Geophys. Res., 115, C09011, doi:10.1029/2009JC005976, 2010b.
Stramma, L., Oschlies, A., and Schmidtko, S.: Mismatch between observed and modeled trends in dissolved upper-ocean oxygen over 50 yr, Biogeosciences, 9, 4045-4057, doi:10.5194/bg9-4045-2012, 2012a.

Stramma, L., Prince, E. D., Schmidtko, S., Luo, J., Hoolihan, J. P., Visbeck, M., Wallace, D. R. W., Brandt, P., and Körtzinger, A.: Expansion of oxygen minimum zones may reduce available habitat for tropical pelagic fishes, Nature Clim. Change, 2, 33-37, 2012b.

Subramanian, A. C., Miller, A. J., Cornuelle, B. D., Di Lorenzo, E., Weller, R. A., and Straneo, F.: A data assimilative perspective of oceanic mesoscale eddy evolution during VOCALS-REx, Atmos. Chem. Phys., 13, 3329-3344, doi:10.5194/acp-13-33292013, 2013.

Thamdrup, B., Dalsgaard, T., and Revsbech, N. P.: Widespread functional anoxia in the oxygen minimum zone of the eastern South Pacific, Deep-Sea Res. Pt. I, 65, 36-45, 2012.

Thomas, L. N. and Lee, C. M.: Intensification of ocean fronts by down-front winds, J. Phys. Oceanogr., 35, 1086-1102, 2005.

Winkler, L. W.: Bestimmung des im Wasser gelösten Sauerstoffs, Ber. Dtsch. Chem. Ges., 21, 2843-2855, 1888. 